\title{
KEMAMPUAN BERBAHASA INGGRIS, MOTIVASI DAN SIKAP TERHADAP BAHASA INGGRIS MAHASISWA PROGRAM STUDI ILMU KEPERAWATAN (S1) STIKES JENDERAL ACHMAD YANI CIMAHI
}

\author{
ENGLISH PROFICIENCY, MOTIVATION AND ATTITUDE TOWARDS ENGLISH AMONG \\ NURSING STUDENTS STIKES JENDERAL ACHMAD YANI CIMAHI
}

\author{
Alvii TB Siregar ${ }^{1}$, Evangeline $\mathrm{H}^{2}$ \\ 1 Universitas Widyatama Bandung, Fakultas Bahasa Jurusan Bahasa Inggris \\ ${ }^{2}$ STIKes Jenderal Ahmad Yani Cimahi \\ Email: alvii.siregar@widyatama.ac.id
}

\begin{abstract}
ABSTRAK
Latar belakang: Penelitian yang dilaksanakan di STIKes Jendral Achmad Yani Bandung tahun 2010 mengindikasikan mahasiswa keperawatan masih mengalami masalah dalam proses belajar mengajar ketika materi yang diberikan berbahasa Inggris. Khususnya textbook, artikel keperawatan dan materi lain yang berbahasa Inggris, masih dianggap sulit untuk dimengerti oleh sebagaian besar mahasiswa. Walaupun motivasi mahasiwa cukup tinggi serta sikap mereka sangat mendukung terhadap pembelajaran dan penggunaan bahasa Inggris, nyatanya responden mendapatkan skor rendah dalam test kemampuan membaca text keperawatan berbahasa Inggris. Tujuan: Penelitian ini bertujuan mendeskripsikan lebih lanjut motivasi dan sikap mahasiswa keperawatan terhadap bahasa Inggris. Metode: Data dikumpulkan dengan melakukan test kemampuan berbahasa Inggris berstandar internasional, serta memberikan kuisioner yang mengukur motivasi dan sikap terhadap bahasa Inggris, kepada mahasiswa keperawatan tingkat 3 (tiga) semester 6, Programs Studi Ilmu Keperawatan S1 Stikes Jenderal Achmad Yani Cimahi. Hasil: Hasil penelitian didapatkan walaupun responden mendapatkan skor yang rendah dalam test kemampuan berbahasa Inggris, mereka memiliki motivasi tinggi dan sikap yang mendukung terhadap bahasa Inggris. Diskusi: Hal ini menggambarkan dibutuhkan metoda yang lebih inovatif dan efektif dalam pembelajaran bahasa Inggris dengan tujuan adanya peningkatan kemampuan berbahasa Inggris mahasiswa keperawatan, khususnya di STIKes Jenderal Achmad Yani Cimahi.
\end{abstract}

Kata kunci : kemampuan berbahasa Inggris, motivasi, sikap

\begin{abstract}
Introduction: A research conducted at STIKes Jenderal Achmad Yani Cimahi in 2010 indicated how students were still experiencing problems with their study where English is mediatory language. In particular, English textbooks, articles, and other resources were considered by the majority of the participants to be difficult to process. Despite their high motivation and attitude towards learning and using English, the participants scored low in their readability tests. Objective: This study continues to investigate factors that influence their ability in using English. It focuses on the factor of the language mastery in relations to the learner's motivation and attitude towards English. Method: The descriptive investigation was conducted with participants from third year students of STIKes Jenderal Ahmad Yani, Cimahi by measuring their English skills with an international standardized English test and giving questionnaires on their attitude and motivation towards the importance of English. Result: The results showed that despite the low scores in the mastery of the language their high motivation and attitude also exhibited a need to have an approach different from the current methods to aid with their English skills enhancement, especially methods in their learning process. Discussion: Thus, insight gained may prove critical in building a suitable English learning program in the institute or other school with similar conditions.
\end{abstract}

Keywords: attitude, English proficiency, English learning, motivation, 


\section{PENDAHULUAN}

Sebagai anggota ASEAN, Indonesia berkewajiban menerima tenaga ahli termasuk di bidang kesehatan dari negara anggota ASEAN yang lain. Sebagai dampaknya persaingan untuk mendapatkan pekerjaan semakin ketat. Hal ini menuntut tenaga profesional dan mahasiswa untuk memiliki kompetensi yang paling tidak sama dengan para pesaingnya. Salah satu kompetensi utama yang diperlukan oleh profesional untuk dapat bersaing dengan tenaga kerja asing dan juga menjadi perhatian Kementerian Riset dan Pendidikan Tinggi serta Kementrian Pendidikan Dasar, adalah penguasaan bahasa Inggris. Bahasa Inggris tidak hanya diperlukan untuk berkomunikasi di tempat bekerja, tetapi berguna juga untuk mengikuti perkembangan ilmu pengetahuan dan teknologi di bidangnya masing-masing.

Kementerian Riset dan Pendidikan Tinggi serta Kementrian Pendidikan Dasar dalam beberapa dekade terakhir telah berupaya menanggapi kebutuhan ini dengan menempatkan Bahasa Inggris dalam kurikulum pendidikan dari tingkat pendidikan dasar sampai tingkat pendidikan tinggi. Materi yang diberikan meningkat secara bertahap dari materi sederhana sampai penguasaan kemampuan berkomunikasi yang lebih kompleks seperti menulis dalam bahasa Inggris yang lebih formal. Salah satu hal yang mejadi fokus perhatian dan perlu dipertimbangkan dalam proses pembelajaran bahasa Inggris adalah faktor yang berhubungan dengan kemampuan peserta didik diantaranya motivasi (Faezi, 2008; Yuti R, 2000) serta sikap mereka terhadap bahasa Inggris itu sendiri (Tomkins, 2010; Torgesen, 2006; Wei, 2007).

Gardner (1985) mendefinisikan motivasi sebagai dorongan untuk melakukan sesuatu untuk mencapai hasil yang diinginkan. Lebih lanjut Gardner menyatakan motivasi dalam mempelajari bahasa Inggris lebih spesifik terdiri dari elemen integratif dan elemen instrumental. Motivasi integratif mendorong seseorang menguasai bahasa asing dengan tujuan ingin menjadi bagian dari komunitas penutur bahasa asing dan berkeinginan untuk dapat berbahasa asing dengan fasih seperti penutur asli. Sedangkan motivasi instumental, lebih kepada keinginan untuk meningkatkan status sosial dan finansial. Johnson (2008), menambahkan keinginan mendapatkan panghasilan yang lebih baik, kekuasaan dan peningkatan jenjang karir pada keuntungan fisik dan pragmatik dari motivasi instrumental. Ke dua motivasi tersebut sejalan dengan pernyataan Ghazvini \& Khajehpour (2011). Mereka mengemukakan bahkan pada jenjang sebelum perguruan tinggi siswa sudah sadar dan dididik untuk lebih menyadari bahwa ke dua motivasi tersebut sangat berguna dalam kehidupan mereka. Oleh karena itu, ke dua jenis motivasi tersebut sama pentingnya dan tergantung pilihan individu tipe motivasi yang mana yang lebih mendorong mereka dalam melakuan sesuatu.

Faktor lain adalah sikap. Latchanna and Dagnew (2009) mendefinisikan sikap sebagai pernyataan evaluatif terhadap objek, orang atau peristiwa. Hal ini mencerminkan perasaan seseorang terhadap sesuatu. Definisi ini berakar dari studi oleh Smith (2008) yang menyatakan bahwa perasaan seseorang terhadap bahasa adalah kepercayaan untuk berhasil dalam menguasai bahasa yang ia pelajari. Kedua ahli di atas juga menekankan bahwa kepercayaan tersebut dapat berubah saat seseorang menyadari capaian kompetensi mereka saat ini. Dapat disimpulkan bahwa sikap mempengaruhi hasil belajar pada tiap tingkat, dan sangat penting untuk mempertahankan sikap positif pada tiap tahap pembelajaran untuk mendapatkan hasil yang diinginkan.

Sikap dapat dibagi lagi menjadi 3 aspek yang lebih spesisfik yaitu kognitif, afektif konatif (Tomkins, 2010; Torgensen , 2007; Wei, 2007). Aspek kognitif berkaitan dengan kemampuan untuk mengerti materi yang dipelajari. Aspek afektif berkaitan dengan 
rasa dan keprecayaan yang dimiliki seseorang yang sedang belajar bahasa. Sedangkan aspek konatif berkaitan dengan tindakan yang akan dilakukan oleh seseorang yang sedang belajar bahasa Inggris dalam proses pembelajaran bahasa. Ketiga aspek ini tergantung pada individu bersangkutan aspek manakah yang lebih dominan. Berdasarkan paparan di atas maka pertanyaan penilitan yang timbul adalah sebagai berikut : apakah motivasi instrumental lebih tinggi dari motivasi integratif pada pelajar di perguruan tinggi? Apakah motivasi yang tinggi dan sikap positif menghasilkan skor kemampuan berbahasa Inggris yang tinggi pula? Pertanyaan pertama bedasarkan pada pemikiran bahwa berdasarkan pada fakta bahwa pelajar perguruan tinggi didorong untuk meraih dan bersaing dalam karir sesuai dengan bidang studi masing-masing. Pertanyaan ke dua memandang dari persipektif bagaimana ke dua aspek tersebut berperan dalam prosem pembelajaran bahasa pada pelajar perguruan tinggi.

\section{METODOLOGI}

Lokasi penelitian ini di STIKes Jendral Achmad Yani Cimahi pada bulan Mei 2017. 51 mahasiswa Program Studi IImu Keperawatan tingkat 3 semester VI bersedia menjadi responden dan mengikuti test kemampuan berbahasa Inggris berstandar internasional, serta mengisi kuesioner motivasi dan sikap terhadap bahasa Inggris. Kemampuan berbahasa Inggris diukur dengan menggunakan test berstandar internasional , terdiri dari listening, structure, dan reading yang terdiri dari 140 pertanyaan. Paket soal test yang digunakan disesuaikan dengan kompetensi standar berbahasa Inggris mahasiswa ditingkat dasar. Test kemampuan berbahasa Inggris berlangsung selama 110 menit (30 menit untuk listening, 25 menit untuk structur dan 55 menit untuk reading). Hasil dari test kemampuan berbahasa Inggris dikonversikan dan dikategorikan berdasarkan standar yang ditetapkan oleh ETS (Educational Testing Service). Tujuan mengkatagorikan skor kemampuan berbahasa Inggris tidak hanya untuk menentukan tingkat penguasaan bahasa Inggris responden, juga untuk melihat kesenjangan antara skor yang diharapkan dan nilai yang diperoleh saat test dilaksnakan.

Instrumen untuk mengukur motivasi dan sikap disusun berdasarkan studi oleh Hyong Yun (2007), dan Faezi (2008) . Kuesioner disusun dalam bahasa Indonesia untuk menghindari ambiguitas dan kesalahpahalaman. Instrumen untuk mengukur sikap terdiri dari 25 pertanyaan berskala Likert. Terdiri dari 25 pernyataan negatif dan positif. Hasil uji validitas adalah sebagai berikut, $r$ hitung Pearson Product Moment dalam rentang $(n=15) 0,532-0,789$ ( $>r$ tabel 0,514), Alpha Cronbach 0,857 (>r tabel). Sehingga dapat disimpulkan bahwa instrument sikap valid dan reliabel untuk digunakan dalam penelitian ini. Hasil uji Kolmogorof Smirnof didapatkan hasil 0,2 $(0,05)$, menunjukkan data berdistribusi normal, sehingga skor sikap dapat dikatagorikan menggunakan rerata perolehan skor responden sebagi berikut, sikap mendukung bila skor $\geq 82$, dan tidak mendukung bila skor yang diperoleh $<82$.

Instrumen untuk mengukur motivasi terdiri dari 25 pertanyaan yang dikembangkan berdasarkan penelitian Hyong Yun (2007), Faezi (2008) dan Hutabarat (2010). Pertanyaan no 1-12 mengukur aspek intergratif sedangkan pertanyaan no 13-25 mengukur aspek instrumental. Hasil uji validitas adalah sebagai berikut, $r$ hitung Pearson Product Moment dalam rentang $(n=15)$ 0,631 - 0,818 (>r tabel 0,514), Alpha Cronbach 0,969 (> r tabel). Sehingga dapat disimpulkan bahwa instrument sikap valid dan reliabel untuk digunakan dalam penelitian ini. Hasil uji Kolmogorof Smirnof didapatkan hasil 0,08 (.0,05), menunjukkan data berdistribusi normal, sehingga skor motivasi dapat dikatagorikan menggunakan rerata perolehan skor responden sebagi berikut motivasi tinggi bila skor $\geq 100$, dan rendah bila skor yang diperoleh $<100$. 


\section{HASIL}

Hasil dari test kemampuan berbahasa Inggris, motivasi dan sikap dapat dilihat pada tabel 1 di bawah ini. Menurut ETS (2000), rerata hasil uji test kemampun bahasa Inggris nasional untuk mahasiswa tingkat awal adalah 535. Hasil yang diperoleh dari penelitian ini tidak satupun responden yang memperoleh skor sesuai dengan rerata nasional tersebut, dengan perolehan skor pada rentang 344 to 490 , dengan rerata skor 387. Sebanyak 40 responden memiiki motivasi tinggi untuk mempelajari bahasa Inggris dan sebagian kecil responden (33\%) memiliki sikap mendukung terhadap bahasa Inggris.

Tabel 1 Distribusi frekuensi hasil test kemampuan berbahasa Inggris, motivasi dan sikap terhadap bahasa Inggris $(n=51)$

\begin{tabular}{c|c|c|c}
\hline Variabel & $\mathbf{N}$ & $\%$ & $\begin{array}{c}\text { Total } \\
\%\end{array}$ \\
\hline
\end{tabular}

Kemampuan berbahasa Inggris

\begin{tabular}{cccc}
\hline 535 & 0 & $0 \%$ & \\
$=535$ & 0 & $0 \%$ & $100 \%$ \\
\hline$<535$ & 51 & $100 \%$ & \\
$\begin{array}{c}\text { Motivasi } \\
\quad \text { Tinggi }\end{array}$ & 40 & $78 \%$ & $100 \%$ \\
$\quad$ Rendah & 11 & $12 \%$ & \\
$\begin{array}{c}\text { Sikap } \\
\quad \text { Mendukung }\end{array}$ & 17 & $33 \%$ & \\
$\quad$ Tidak & 34 & $67 \%$ & $100 \%$ \\
\hline mendukung & & & \\
\hline
\end{tabular}

Variabel motivasi seperti yang dapat dilihat pada tabel 2 didapatkan hasil $78 \%$ responden memilki motivasi tinggi untuk mempelajari serta menggunakan bahasa Inggris dalam berbagai kesempatan dan lingkungan yang berbeda. $32 \%$ responden memilih setuju untuk motivasi integratif dan $48 \%$ responden memilih setuju untuk motivasi instrumental). 38\% responden memilih sangat setuju untuk motivasi integratif dan $28 \%$ responden setuju untuk motivasi instrumental.

Tabel 2 Kuesioner Motivasi belajar bahasa Inggris

\begin{tabular}{|c|c|c|c|c|c|c|}
\hline \multicolumn{7}{|c|}{ INTEGRATIF } \\
\hline \multicolumn{2}{|c|}{ Pertanyaan } & SS & $\mathbf{S}$ & $\mathbf{N}$ & TS & STS \\
\hline \multicolumn{7}{|c|}{ Saya belajar bahasa Inggris karena } \\
\hline P1 & $\begin{array}{l}\text { tanpa menguasai bahasa Inggris saya tidak akan sukses dibidang } \\
\text { apapun }\end{array}$ & 19 & 23 & 7 & 0 & 2 \\
\hline $\mathbf{P 2}$ & $\begin{array}{l}\text { saya akan dapat berkomunikasi dengan orang-orang yang berasal } \\
\text { dari berbagai tempat di dunia. }\end{array}$ & 34 & 15 & 0 & 1 & 1 \\
\hline P3 & saya dapat membaca dan memahami buku berbahasa Inggris & 25 & 18 & 7 & 1 & 0 \\
\hline $\mathbf{P 4}$ & saya dapat mengerti film, video, lagu, radio berbahasa Inggris. & 28 & 18 & 4 & 1 & 0 \\
\hline P5 & $\begin{array}{l}\text { saya seorang yang berpendidikan sudah seharusnya dapat } \\
\text { berbahasa Inggris dengan baik. }\end{array}$ & 27 & 17 & 6 & 0 & 1 \\
\hline P6 & saya memang sangat senang belajar bahasa asing. & 6 & 12 & 22 & 9 & 2 \\
\hline P7 & saya yakin saya akan sukses. & 14 & 24 & 8 & 2 & 3 \\
\hline P8 & $\begin{array}{l}\text { saya akan tahu lebih banyak kejadian-kejadian terkini diseluruh } \\
\text { dunia. }\end{array}$ & 17 & 25 & 8 & 0 & 1 \\
\hline P9 & $\begin{array}{l}\text { saya akan dapat mencari informasi dan materi berbahasa Inggris } \\
\text { yang saya butuhkan di internet. }\end{array}$ & 17 & 26 & 7 & 0 & 1 \\
\hline P10 & $\begin{array}{l}\text { saya akan lebih dihormati bila saya dapat berbahasa Inggris } \\
\text { dengan baik. }\end{array}$ & 10 & 25 & 12 & 4 & 0 \\
\hline P11 & $\begin{array}{l}\text { saya yakin saya akan mendapat pekerjaan yang bagus bila saya } \\
\text { dapat berbahasa Inggris dengan baik. }\end{array}$ & 17 & 30 & 1 & 3 & 0 \\
\hline & $\begin{array}{l}\text { akan membuat saya menjadi orang yang mempunyai banyak } \\
\text { ilmu }\end{array}$ & 19 & 23 & 8 & 1 & 0 \\
\hline
\end{tabular}




\begin{tabular}{|c|c|c|c|c|c|c|}
\hline \multicolumn{7}{|c|}{ INSTRUMENTAL } \\
\hline \multicolumn{2}{|c|}{ Pertanyaan } & SS & $\mathbf{S}$ & $\mathbf{N}$ & TS & STS \\
\hline \multicolumn{7}{|c|}{ Saya belajar bahasa Inggris karena } \\
\hline P13 & akan menunjang karir saya nantinya. & 28 & 16 & 5 & 1 & 1 \\
\hline P14 & $\begin{array}{l}\text { saya ingin tahu lebih banyak mengenai petutur asli bahasa } \\
\text { Inggris (native speaker). }\end{array}$ & 14 & 24 & 8 & 4 & 1 \\
\hline P15 & $\begin{array}{l}\text { sebagai persyaratan bila saya akan meneruskan jenjang } \\
\text { pendidikan saya nanti. }\end{array}$ & 19 & 27 & 4 & 0 & 1 \\
\hline P16 & belajar bahasa Inggris sangat menantang bagi saya. & 11 & 21 & 13 & 5 & 1 \\
\hline P17 & $\begin{array}{l}\text { dengan menguasai bahasa Inggris saya akan dapat terus } \\
\text { berhubungan dengan sahabat dan kenalan saya. }\end{array}$ & 10 & 25 & 11 & 4 & 1 \\
\hline P18 & $\begin{array}{l}\text { dengan menguasai bahasa Inggris saya akan lebih banyak tahu } \\
\text { ragam budaya dan bangsa di dunia }\end{array}$ & 14 & 30 & 4 & 3 & 0 \\
\hline P19 & $\begin{array}{l}\text { semakin banyak saya tahu mengenai petutur asli (orang bule) } \\
\text { semakin saya menyukai mereka. }\end{array}$ & 3 & 25 & 19 & 4 & 0 \\
\hline $\mathbf{P 2 0}$ & $\begin{array}{l}\text { dengan menguasai bahasa Inggris saya akan dapat mengerti } \\
\text { lagu-lagu pop berbahasa Inggris }\end{array}$ & 16 & 23 & 7 & 5 & 0 \\
\hline $\mathbf{P 2 1}$ & $\begin{array}{l}\text { saya akan dapat lebih memahami gaya hidup orang-orang yang } \\
\text { tinggal di negara yang menggunakan bahasa Inggris. }\end{array}$ & 10 & 26 & 10 & 5 & 0 \\
\hline P22 & $\begin{array}{l}\text { saya dapat lebih aktif dalam kegiatan berbagai suku bangsa } \\
\text { dan budaya. }\end{array}$ & 10 & 27 & 11 & 3 & 0 \\
\hline $\mathbf{P 2 3}$ & $\begin{array}{l}\text { membuat saya lebih menghargai seni dan literatur berbahasa } \\
\text { Inggris. }\end{array}$ & 11 & 28 & 9 & 3 & 0 \\
\hline P24 & $\begin{array}{l}\text { membuat saya dapat bertemu dan becakap-cakap dengan lebih } \\
\text { banyak orang dari berbagai suku bangsa. }\end{array}$ & 21 & 23 & 4 & 3 & 0 \\
\hline P25 & $\begin{array}{l}\text { dengan belajar bahasa Inggris saya dapat lebih mudah bergaul } \\
\text { dengan petutur asli. }\end{array}$ & 17 & 24 & 6 & 4 & 0 \\
\hline
\end{tabular}

Pada variabel sikap seperti yang dapat dilihat pada tabel 3, 33\% memiliki sikap mendukung terhadap pembelajaran bahasa Inggris dan sedangkan $67 \%$ memiliki sikap tidak mendukung terhadap pembelajaran bahasa Inggris. Dari aspek kognitif 20 responden memilih jawaban tidak setuju untuk pertanyaan "Mata ajar bahasa Inggris tidak harus ada dalam kurikulum pendidikan program studi IImu Keperawatan". 21 responden memilih jawaban tidak setuju untuk pertanyaan "Saya lebih mudah mengerti bahasa Inggris dibanding mata ajar yang lain". Unutk pertanyaan "Saya merasa selalu bersemangat saat belajar bahasa Inggris" dan "Saat pelajaran bahasa Inggris di kelas saya ingin sekali pelajaran tersebut cepat selesai", 19 responden memilih jawaban tidak setuju. Pada aspek koantif sebanyak 9 responden memilih jawaban "Saat pelajaran bahasa Inggris saya sering mengerjakan hal lain seperti mengirim sms, browsing, dll".

Tabel 3 Kuesioner sikap terhadap bahasa Inggris dan belajar bahasa Inggris

\begin{tabular}{|lllllll}
\hline KOGNITIF & SS & S & N & TS & STS \\
\hline $\begin{array}{l}\text { Pertanyaan } \\
\text { P1 }\end{array}$ & $\begin{array}{l}\text { Mata ajar bahasa Inggris tidak harus ada dalam kurikulum } \\
\text { pendidikan program studi Ilmu Keperawatan. }\end{array}$ & 5 & 4 & 20 & 19 \\
\hline $\begin{array}{l}\text { Pahasa Inggris adalah salah satu mata ajar yang sulit } \\
\text { dipahami. }\end{array}$ & 22 & 12 & 8 & 1 \\
\hline
\end{tabular}




\begin{tabular}{|c|c|c|c|c|c|c|}
\hline P8 & Kemampuan berbahasa Inggris saya semakin baik. & 0 & 15 & 29 & 7 & 0 \\
\hline P11 & $\begin{array}{l}\text { Setelah saya belajar bahasa Inggris selama dibangku kuliah } \\
\text { saya merasa pemahaman saya terhadap bahasa Inggris tidak } \\
\text { menjadi lebih baik. }\end{array}$ & 2 & 15 & 13 & 17 & 4 \\
\hline P12 & $\begin{array}{l}\text { Saya menjadi malas belajar bahasa Inggris karena kosa kata } \\
\text { yang harus saya hapal sangat banyak. }\end{array}$ & 4 & 11 & 17 & 16 & 3 \\
\hline P19 & $\begin{array}{l}\text { Nilai bahasa Inggris saya selalu lebih baik dari nilai mata ajar } \\
\text { lain. }\end{array}$ & 2 & 12 & 23 & 13 & 1 \\
\hline P20 & $\begin{array}{l}\text { Saya selalu memperoleh nilai yang rendah untuk mata ajar } \\
\text { bahasa Inggris. }\end{array}$ & 3 & 9 & 12 & 23 & 4 \\
\hline $\mathbf{P 2 3}$ & $\begin{array}{l}\text { Saya lebih mudah mengerti bahasa Inggris dibanding mata } \\
\text { ajar yang lain. }\end{array}$ & 1 & 6 & 15 & 21 & 8 \\
\hline \multicolumn{7}{|c|}{ AFEKTIF } \\
\hline \multicolumn{2}{|c|}{ Pertanyaan } & SS & $\mathbf{S}$ & $\mathbf{N}$ & TS & STS \\
\hline P6 & Bahasa Inggris adalah pelajaran kesukaan saya. & 2 & 7 & 27 & 11 & 4 \\
\hline P7 & $\begin{array}{l}\text { Saat pelajaran bahasa Inggris di kelas saya ingin sekali } \\
\text { pelajaran tersebut cepat selesai. }\end{array}$ & 7 & 9 & 14 & 19 & 2 \\
\hline P17 & $\begin{array}{l}\text { Saya merasa senang bila jam pelajaran bahasa Inggris } \\
\text { ditambah. }\end{array}$ & 3 & 10 & 22 & 12 & 4 \\
\hline P18 & $\begin{array}{l}\text { Saya merasa senang bila materi pelajaran yang lain diberikan } \\
\text { juga dalam bahasa Inggris. }\end{array}$ & 1 & 11 & 17 & 13 & 9 \\
\hline P24 & Saya merasa selalu bersemangat saat belajar bahasa Inggris & 2 & 14 & 26 & 5 & 4 \\
\hline P25 & $\begin{array}{l}\text { Menurut saya pelajarang bahasa Inggris sangat } \\
\text { membosankan. }\end{array}$ & 6 & 3 & 19 & 19 & 4 \\
\hline \multicolumn{7}{|c|}{ KONATIF } \\
\hline \multicolumn{2}{|c|}{ Pertanyaan } & SS & $\mathbf{S}$ & $\mathbf{N}$ & TS & STS \\
\hline P3 & $\begin{array}{l}\text { Saat pelajaran Bahasa Inggris saya memperhatikan dengan } \\
\text { sungguh-sungguh. }\end{array}$ & 1 & 25 & 20 & 3 & 2 \\
\hline P4 & $\begin{array}{l}\text { Saat pelajaran bahasa Inggris saya sering mengerjakan hal } \\
\text { lain seperti mengirim sms, browsing, dll. }\end{array}$ & 2 & 21 & 14 & 9 & 5 \\
\hline P5 & $\begin{array}{l}\text { Agar dapat menguasai bahasa Inggris dengan baik saya perlu } \\
\text { mengikuti les tambahan disamping pelajaran yang saya dapat } \\
\text { di kelas. }\end{array}$ & 16 & 18 & 10 & 3 & 4 \\
\hline P9 & $\begin{array}{l}\text { Saat mempelajari materi yang sulit dipahami dari mata ajar } \\
\text { bahasa Inggris membuat saya tidak ingin melanjutkan balajar } \\
\text { bahasa Inggris. }\end{array}$ & 8 & 8 & 11 & 21 & 3 \\
\hline P10 & $\begin{array}{l}\text { Walaupun beberapa materi bahasa Inggris, saya anggap sulit } \\
\text { dipahami, saya akan terus belajar sampai saya dapat } \\
\text { berbahasa Inggris dengan baik. }\end{array}$ & 13 & 24 & 10 & 4 & 0 \\
\hline P13 & $\begin{array}{l}\text { Saya selalu mengerjakan tugas mata ajar bahasa Inggris yang } \\
\text { diberikan dikelas walaupun saya rasa sangat sulit. }\end{array}$ & 11 & 28 & 10 & 2 & 0 \\
\hline P14 & $\begin{array}{l}\text { Jika saya mendapat kesulitan dalam mengerjakan tugas } \\
\text { bahasa Inggris yang diberikan dikelas, saya tidak akan } \\
\text { mengerjakan tugas yang diberikan.. }\end{array}$ & 2 & 4 & 3 & 35 & 7 \\
\hline P15 & $\begin{array}{l}\text { Saya sering berdiskusi menggunakan bahasa Inggris dengan } \\
\text { teman-teman saya. }\end{array}$ & 6 & 9 & 24 & 12 & 0 \\
\hline P16 & $\begin{array}{l}\text { Saat jadwal pelajaran bahasa Inggris saya sering berpura- } \\
\text { pura sakit. }\end{array}$ & 0 & 0 & 1 & 20 & 30 \\
\hline P21 & $\begin{array}{l}\text { Saat diberi tugas oleh dosen saya sering mencari artikel atau } \\
\text { jurnal berbahasa Inggris. }\end{array}$ & 0 & 10 & 29 & 10 & 2 \\
\hline P22 & $\begin{array}{l}\text { Saya tidak suka membaca buku sumber mata ajar yang } \\
\text { berbahasa Inggris. }\end{array}$ & 3 & 14 & 21 & 10 & 3 \\
\hline
\end{tabular}




\section{DISKUSI}

Berdasarkan hasil penelitian ditemukan bahwa responden memiliki motivasi instrumental lebih tinggi dari motivasi integratif. Pada penelitian ini responden menilai kedua tipe motivasi sama pentingnya, walaupun secara teori seorang yang sedang menempuh pendidikan di jenjang universtias, motivasi belajar bahasa Inggris adalah untuk menyanggupkan mereka untuk bersaing lebih kompetitif di dunia kerja. Mereka beranggapan bahwa kemampuan untuk berkomunikasi dalam bahasa Inggris dengan baik menyamai petutur asli dan dikenal orang banyak karena kemampuan mereka berbahasa Inggris, sama pentingnya dengan tujuan untuk meraih jenjang karir dan penghargaan yang diperoleh. Walaupun responden mengindikasikan memiliki motivasi yang tinggi untuk belajar bahasa Inggris, serta memiliki sikap yang mendukung terhadap bahasa Inggris, hasil test kemampuan berbahasa Inggris mereka tidak merefleksikan hal yang sejalan. Pada nyatanya seluruh mahasiswa belum mencapai skor standar kemampuan berbahasa Inggris untuk mahasiswa perguruan tinggi.

Hasil penelitian ini dapat dijelaskan lebih spesifik dengan menyoroti butir pertanyaan dari kuesioner yang digunakan untuk mengumpulkan data penelitin. Hal pertama terkait pada aspek motivasi yang menjadi prioritas responden. Di antara motivasi integratif skor paling tinggi terletak pada komponen bahwa karakteristis petutur asli menjadi hal penting yang memotivasi mereka untuk belajar bahasa Inggris (P1, $P 2$, $P 4$ dan $P$ 12). Hal ini mengindikasikan, responden ingin menjadi bagian dari komunitas petutur bahasa Inggris agar dikenal memiliki kemampuan berbahas Inggris dengan baik. Aktualisasi diri juga dianggap penting dan menjadi prioritas (P7, P9, P11, P22). Demikian pula dengan pemahaman berbagai karya seni dan budaya seperti musik dan literatur berbahasa Inggris dianggap sebagai suatu capaian yang krusial.

Hal lain yang perlu disoroti adalah kepekaan responden terkait kemampuan individual, seperti yang dinyatakan pada pertanyaan no 8, 11, 19 dan 23 yang menjadi komponen pada aspek kognitif dari kusioner sikap. Pertanyaan no 8 terkait evaluasi tehadap kemampua bahasa Inggris mereka di luar proses belajar mengajar di bangku kuliah. Sedangkan no 11 mengungkapkan umpan balik mereka setelah belajar bahasa Inggris selama duduk dibangku perkuliahan. Kontradiksi ini mengindikasikan mereka mengalami peningkatan kemampuan berbahasa Inggris tetapi belum merasa memerlukan pentingnya dapat berbahasa Inggris pada tahapan pendidikan.

Kontradiksi lain dapat dilihat pada variabel sikap, sebagain besar responden menganggap bahasa Inggris bukan mata ajar yang favorit, seperti yang dapat dilihat pada pertanyaan no 6 dan 4, walaupun sebagian responden merasa bersemangat ketika belajar bahasa Inggris. Hal menarik lain dapat dilihat pada variabel sikap pada komponen konatif. Walaupun responden menunjukkan sikap yang tidak mendukung dalam mempelajari bahasa Inggris, responden menyatakan bahwa mata ajar bahasa Inggris perlu dimasukkan ke dalam kurikulum perguruan tinggi dan menyatakan perlu menambah jam belajar bahasa Inggris di luar apa yang mereka dapat di kelas. Temuan lain yang menarik adalah sebagian besar respoden menyatakan berusaha menyelesaikan tugas pada mata ajar bahasa Inggris juga mencari materi berbahasa Inggris bila diperlukan dalam menyelesaikan tugas mataajari lain walaupun merasa hal ini tidak mudah.

\section{KESIMPULAN}

Responden pada peneltian ini memiliki motivasi yang tinggi untuk mempelajari bahasa Inggris. Demikian pula dengan variabel sikap di mana responden menunjukkan sikap yang mendukung 
terhadap bahasa Inggris dan belajar bahasa Inggris. Tetapi hal ini tidak sejalan dengan kemampuan berbahasa Inggris mereka, di mana mahasiswa tingkat tiga telah mendapatkan mata ajar bahasa Inggris selama 9 tahun sejak mereka duduk di bangku SMP. Dapat disimpulkan aspek yang perlu disoroti adalah pengalaman pembelajaran bahasa itu sendiri. Sangat direkomendasikan untuk menemukan metode mengajar bahasa Inggris yang efektif dalam meningkatkan kemampuan berbahasa Inggris di saat yang sama mempertahankan motivasi dan sikap yang positif terhadap bahasa Inggris dan proses pembelajarannya serta mengarahkan peserta didik akan pentingnya berbahasa Inggris dalam kehidupan mereka di masa depan.

\section{REFERENSI}

Benraghda, A (2015). Attitudes among International University Students in Delivering English Oral Presentation in Academic Settings, International Journal of English and Education ISSN: 2278-4012, Volume:4, Issue:1

ETS (2007). Test and Score Data Summary for TOEFL® Internet-based and Paper-based Tests JANUARY 2007DECEMBER 2007 TEST DATA

$\begin{array}{llr}\text { Faezi, Z (2008). } & \text { Language } & \text { Learning } \\ \text { Motivation } & \text { among } & \text { Iranian } \\ \text { Undegraduate } & \text { Students, } & \text { World } \\ \text { Applied Sceinces Journal 5(1):54-61, } & \\ 2008 & \end{array}$

Ghazvinia, S \& Khajehpoura, S (2011). Attitudes and Motivation in Learning English as Second Language in High School Students, Procedia Social and Behavioral Sciences 15 (2011) 12091213

Hutabarat, E (2010). Influencing Factors on English Health Care Test Reading Abilty of 3rd Year Students of Stikes Jenderal Ahmad Yani Cimahi, 1st Java International Nursing Conference Proceeding, Universitas Diponegoro, Semarang

Johnson, K (2008). An Introduction to Foreign Language Learning and Teaching. 2nd edition. New York: Pearson. ISBN 9781-40583-617-3

Khalid, A (2016). A Study of the Attitudes and Motivational Orientations of Pakistani Learners Towards the Learning of English as a Second Language, SAGE Open July-September 2016: 1-19 (C) The Author(s) 2016 DOI: 10.1177/2158244016665887

Smith, A.N ( 2008). An Introduction to Foreign Language Learning and Teaching. 2nd edition. New York: Pearson. ISBN 978-1-40583-617-3

Wei, M (2007). The Interrelatedness of Affective Factors in EFL Learning, an Examination of Motivational Patterns in Relation to Anxiety in China, TESL Journal, June 2007, volume 11 number 11. 